\title{
凹形円曲面上の射流 \\ SUPERCRITICAL FLOW ON THE CIRCULARLY CURVED FACE
}

\author{
渡 部 儀 三 郎* \\ By Gisabro WATANABE
}

\section{1. まえがき}

スキージャンプ減勢工の凹形円曲面上の流れは，遠心 力の影響を大きく受けるものと考える.

水深 $h_{0}$ と円曲面の半径 $R$ との比 $h_{0} / R$ を, 水深比と よぶものとすると，たとえば，ダムに設けるスキージャ ンプ減勢工においては, 水深比が比較的小さいが, 海岸 堤防の護岸上部に設けられるパラペットウォール1)上の 流れは, 水深比が大きい場合が多い.

平均流速を $v$, 水深を $h$, 水平に対する曲面接線の傾 斜角を $\theta_{*}$, 断面平均の比エネルギーを $E$ とするとき, Jeager は曲面上の流れについて, 次式を提案している ${ }^{2)}$.

$$
E=\frac{\alpha v^{2}}{2 g}+\lambda h \cos \theta_{*}
$$

ここに, $\lambda$ は Jeager の圧力分布補正係数で, 凹形曲面 のときは $\lambda>1$ としている.

$\alpha \doteqdot 1$ とすると, 曲面上の平均流速は次式で表わされ る.

$$
v=\sqrt{2 g\left(E-i h \cos \theta_{*}\right)}
$$

本実験においては, 水深比の大きい円曲面上の流れの平 均流速について実験し，また，円曲面から空中への射出 水の射出角についても検討した.

本研究により, 水深比の大きい円曲面上の流れの平均 流速は，次式で表わされることを提案した.

$$
V_{m}=K \xi \sqrt{2 g\left(E-h \cos \theta_{*}\right)}
$$

$こ こ に$

$\xi:$ 遠心力係数

$K:$ 平均流速補正係数

上式において $\sqrt{2 g\left(E-h \cos \theta_{*}\right)}$ は，水平との傾斜角 $\theta_{*}$ の直線水路床上の流れの平均流速を表わし，これに 補正倸数 $K \xi$ を乗じ，円曲面上の平均流速とする．ま た, 円曲面終点における接線の水平に対する傾斜角と,

* 正会員 高松工業高等専門学校教授 土木工学科
円曲面を通過して空中へ射出する水脈の射出角とは，理 論上は一致するはずであるが，水深比の大きい円曲面上 の流れの場合は一致せず, 偏角 $\Delta \theta$ を生ずる.

スキージャンプ減勢工については, 射出偏角の值がか われば, 円曲面から空中への射出方向が変化し, 同一の 射出流速の場合においても, 射出水脈の水平到達距離と 最大高度がかわるものと考える。

海岸堤防の護岸の上部に設けるパラペットウォールに ついては，波が護岸に衝突して，護岸をそ上するとき， 海水が堤防の背後に越波しないように，パラペットウォ ールを計画するらえで，この偏角 $\Delta \theta$ が一つの因子とな るものと考える.

従来，この偏角を無視する場合が多い上うに考える が，特に，水深比の大きい円曲面上の流れにおいては， 相当大きい偏角を生ずることが考えられるので，これに ついても実験することとした.

\section{2. 凹形円曲面上の流れ}

図一1 に示すように，円弧の始点 Aから中心角 $\theta$ の位 置の断面亚について, 流れの中に円の中心から半径 $r$ の 位置に, 微小水粒 $d s \times d r \times 1$ の近似的直方体をとる. 半径 $r$ の位置の静水圧を $p$ とし, 遠心力を考虑して半 径方向の力のつり合いを考えると, 次式が成立する ${ }^{3)}$.

$$
\begin{aligned}
(p & \left.-\frac{\partial p}{\partial r} \frac{d r}{2}\right) d s-\left(p+\frac{\partial p}{\partial r} \frac{d r}{2}\right) d s \\
& +\rho g d s d r \cos (\theta-\varphi)+\rho d s d r \frac{v^{2}}{r}=0
\end{aligned}
$$

これより次式が得られる.

$$
\frac{1}{\rho} \frac{\partial p}{\partial r}-g \cos (\theta-\varphi)-\frac{v^{2}}{r}=0
$$

水路底の円弧の接線方向に $x$ 軸を，また，円の中心方向 に $y$ 軸をとり， $x$ 軸と $y$ 軸の原点をとおる水平線を基準 線にとり, 損失水頭を無視してベルヌイーの定理を適用 する. 


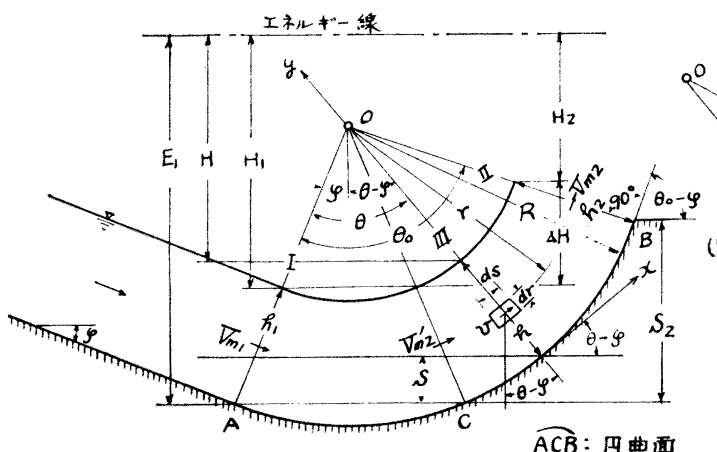

$\widehat{A C B} ：$ 田曲面

図-1

基淮線から円弧始点までの高さを $S$ とし, 円弧始点 の比エネルギーを $E_{1}$ とすると，断面亚について

$$
\frac{p}{\rho g}+y \cos (\theta-\varphi)+\frac{v^{2}}{2 g}=E_{1} \pm S=\text { 一定 } \cdots
$$

ただし，断面亚の位置が $\overparen{\mathrm{AC}}$ 上にあるときは（+）を，

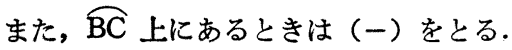

$$
r=R-y \text { であるから }
$$

$$
\frac{\partial p}{\partial r}=\frac{\partial p}{\partial y} \frac{\partial y}{\partial r}=-\frac{\partial p}{\partial y}
$$

式（2）をyについて微分すると

$$
-\frac{1}{\rho} \frac{\partial p}{\partial y}=g \cos (\theta-\varphi)+v \frac{\partial v}{\partial y}
$$

式（3），(4) を式（1）に代入し，次式を得る.

$$
\frac{\partial v}{\partial y}=\frac{v}{r}=\frac{v}{R-y} \text { また } v(R-y)=\text { 一定 }
$$

水路底面の流速を $v_{b}$, 水表面の流速を $v_{s}$ とし, $x$ 軸か ら $y$ の位置の流速を $v$ とすると

$$
v_{b} R=v_{s}(R-h)=v(R-y)
$$

式（2）において, $y=h$ のとき $p=0$ であるから

$$
\begin{aligned}
& E_{1} \pm S-h \cos (\theta-\varphi)-\frac{v_{s}{ }^{2}}{2 g}=0 \\
& v_{s}=\sqrt{2 g\left\{E_{1} \pm S-h \cos (\theta-\varphi)\right\}}
\end{aligned}
$$

式 (5)，(6) より

$$
v=\frac{R-h}{R-y} \sqrt{2 g\left\{E_{1} \pm S-h \cos (\theta-\varphi)\right\}} .
$$

単位幅当りの流量 $q$ は, 円弧始点から中心角 $\theta$ の位置 の, 断面而について

$$
\begin{aligned}
q & =\int_{0}^{h} v d y \\
& =(R-h) \sqrt{2 g\left\{E_{1} \pm S-h \cos (\theta-\varphi)\right\}} \int_{0}^{h} \frac{d y}{R-y} \\
& =(R-h)\left(\log _{e} \frac{R}{R-h}\right) \sqrt{2 g\left\{E_{1} \pm S-h \cos (\theta-\varphi)\right\}}
\end{aligned}
$$

断面吕の平均流速を $v_{m}$ とすると

$$
v_{m}=\left(\frac{R-h}{h} \log _{e} \frac{R}{R-h}\right) \sqrt{2 g\left\{E_{1} \pm S-h \cos (\theta-\varphi)\right\}}
$$

円弧の始点をとおる断面Ｉと，

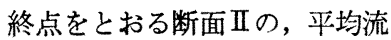
速をそそれぞれ $v_{m 1}, v_{m 2}$ とす ると, 図一1に示すと㧍り断面 I においては $h=h_{1}, \theta=0, S=$

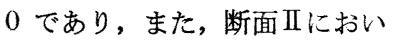
ては $h=h_{2}, \theta=\theta_{0}, S=S_{2}$ であ るから式 (8) より

$$
\begin{aligned}
v_{m 1} & =\left(\frac{R-h_{1}}{h_{1}} \log _{e} \frac{R}{R-h_{1}}\right) \\
& \times \sqrt{2 g\left(E_{1}-h_{1} \cos \varphi\right)}
\end{aligned}
$$

$$
\begin{aligned}
v_{m 2}= & \left(\frac{R-h_{2}}{h_{2}} \log _{e} \frac{R}{R-h_{2}}\right) \\
& \times \sqrt{2 g\left\{E_{1}-S_{2}-h_{2} \cos \left(\theta_{0}-\varphi\right)\right\}} \cdots
\end{aligned}
$$

いま， $\xi$ を次のように掠きこれれ遠心力係数とよぶも のとする.

$$
\left.\begin{array}{l}
\xi=\frac{R-h}{h} \log _{e} \frac{R}{R-h}=\frac{1-\frac{h}{R}}{\frac{h}{R}} \log _{e} \frac{1}{1-\frac{h}{R}} \\
\xi_{1}=\frac{R-h_{1}}{h_{1}} \log _{e} \frac{R}{R-h_{1}}=\frac{1-\frac{h_{1}}{R}}{\frac{h_{1}}{R}} \log _{e} \frac{1}{1-\frac{h_{1}}{R}} \\
\xi_{2}=\frac{R-h_{2}}{h_{2}} \log _{e} \frac{R}{R-h_{2}}=\frac{1-\frac{h_{2}}{R}}{\frac{h_{2}}{R}} \log _{e} \frac{1}{1-\frac{h_{2}}{R}}
\end{array}\right\}
$$

円弧始点, 終点㧍よび円弧上任意の点の水表面の流速を それぞれ $v_{s 1}, v_{s 2}, v_{s}$ とし $H, H_{1}, H_{2}$ を図一1 に示 すように水面からエネルギー線までの高さとすると，そ れぞれの断面の平均流速は次のように表わされる.

$$
\begin{aligned}
v_{m} & =\xi v_{s}=\xi \sqrt{2 g\left\{E_{1} \pm S-h \cos (\theta-\varphi)\right\}} \\
& =\xi \sqrt{2 g H} \\
v_{m 1} & =\xi_{1} v_{s 1}=\xi_{1} \sqrt{2 g\left(E_{1}-h_{1} \cos \varphi\right)} \\
& =\xi_{1} \sqrt{2 g H_{1}} \\
v_{m 2} & =\xi_{2} v_{s 2}=\xi_{2} \sqrt{2 g\left\{E_{1}-S_{2}-h_{2} \cos \left(\theta_{0}-\varphi\right)\right\}} \\
& =\xi_{2} \sqrt{2 g H_{2}}
\end{aligned}
$$

式 (11) のように, 遠心力係数 $\xi$ は, 水深比 $h / R$ の関 数として表わすことができるので，水梁比 $h / R$ と遠心 力係数 $\xi$ の関係を図示すると, 図一2 のとおりである. 実験によれば, 円曲面終点の平均流速は, 水深比 $h / R$ が小さい場合は, 式 (12) で求めた值よりわずかに小さ い值を示した。これは円曲面の摩擦の影響が大きいため と思う. また, 水深比が大きい場合は, 平均流速が式 (12) で求めたものより大きい值を示した. 水深比が大 きくなるにしたがって，円曲面上の流れの水面形が，円 


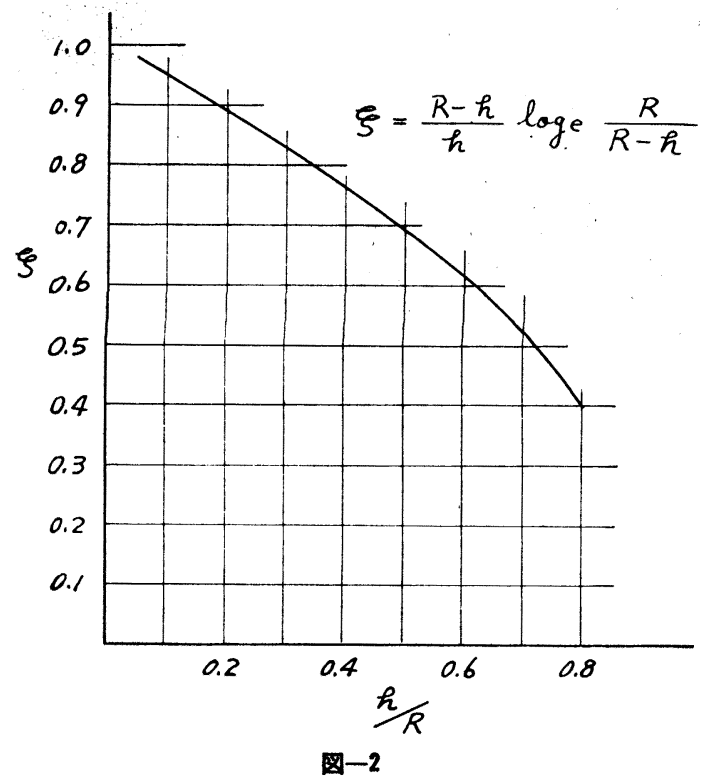

弧と若干異なる曲面を示すようになり，この傾向は水深 比が 1 に近ゔくにしたがって，著しくなることが実験に より推測せられた.このように水深比の大きい流れは, 円曲面の摩擦の影響が小さくなることに加えて, 円曲面 終点水表面の曲率半径が, 円運動と考えたものより大き い值をとり，遠心力の影響が減少するためでないかと推 察する. 本実験のように, 水墚比の大きい凹形円弧の縦 断形水路の平均流速公式を, 次のようにおくものとす る.

$$
\begin{aligned}
V_{m} & =K \xi v_{s}=K \xi \sqrt{2 g\left\{E_{1} \pm S-h \cos (\theta-\varphi)\right\}} \\
& =K \xi \sqrt{2 g H} \\
V_{m 1} & =K_{1} \xi_{1} v_{s 1}=K_{1} \xi_{1} \sqrt{2 g\left(E_{1}-h_{1} \cos \varphi\right)} \\
& =K_{1} \xi_{1} \sqrt{2 g H_{1}} \\
V_{m 2} & =K_{2} \xi_{2} v_{s 2} \\
& =K_{2} \xi_{2} \sqrt{2 g\left\{E_{1}-S_{2}-h_{2} \cos \left(\theta_{0}-\varphi\right)\right\}} \\
& =K_{2} \xi_{2} \sqrt{2 g H_{2}}
\end{aligned}
$$

ここで, $K, K_{1}, K_{2}$ は, それぞれ, 円弧上任意の断面, 円弧の始点断面, 円弧の終点断面における, 平均流速補 正係数とする.

この補正係数と水媣比の関係につき実験 することとした.

\section{3. 射出水の 射出流速と 水平到達距 離および最大高度}

水路の綐断形が，円弧からなる曲線部か ら，その接線方向の直線部に接続するよう な水路について, 曲線部之直線部の平均流 速について考えるものとする.
円弧終点における平均流速は，式（13）により次式で 表わされる.

$$
\begin{aligned}
V_{m 2} & =K_{2} \xi_{2} v_{s 2} \\
& =K_{2} \xi_{2} \sqrt{2 g\left\{E_{1}-S_{2}-h_{2} \cos \left(\theta_{0}-\varphi\right)\right\}}
\end{aligned}
$$

さらに, 流れが円弧部から直線部に流入直後の平均流速 は，遠心力の影響を受けなくなるから， $K_{2} \xi_{2} \doteqdot 1$ と考え られ，その平均流速 $V_{m 2}{ }^{\prime}$ は次式で表わされる.

$$
V_{m 2}{ }^{\prime} \doteqdot v_{s 2}=\sqrt{2 g\left\{E_{1}-S_{2}-h_{2} \cos \left(\theta_{0}-\varphi\right)\right\}}
$$

また，図一3に示すように，流れが円弧からなる縦断形 水路の円弧部から空中に射出する場合についても, 空中 に射出直後の平均流速法 $V_{m 2}{ }^{\prime} \doteqdot v_{s 2}$ と考えられる.

このように空中に射出した射出水の径路は, 空気の抵 抗を無視すれば，放物線と考えることができる．川上の 研究 (5)にれば, 消火用ノッズルによる放水ゼットの水 平到達距離は, 射出初速度 $v_{s 2}=8.6 \mathrm{~m} / \mathrm{s}$ 以下の場合は, 空気の抵抗の影響がほとんどないとしている. 本実験に おいては, $v_{s 2}=2.2 \mathrm{~m} / \mathrm{s} \sim 3.0 \mathrm{~m} / \mathrm{s}$ であることから, 円 曲面からの射出水においても，空気の抵抗による影響は 無視できるものと思う.

図一3に示すように, 円弧部から空中一射出する初速 度を $v_{s 2}$ とし，水平に対する射出角を $\theta_{s 2}$ とする. 図の ように $x$ 軸, $y$ 軸をとり, 空気の抵抗を無視すると, 射 出水流の径路は，次式で表わされる放物線となる.

$$
\begin{aligned}
& x=v_{s 2} \cos \theta_{s 2} \cdot t \ldots \ldots \ldots . \\
& y=v_{s 2} \sin \theta_{s 2} \cdot t-\frac{1}{2} g t^{2}
\end{aligned}
$$

射出水流の 水平到達距離を $L$, 最大高度を $H_{0}$ とする と, $d y / d t=0$ を満足する時間が, 最大高度に到達する までの時間 $T$ を表わす. すなわち

$$
T=\frac{v_{s 2}}{g} \sin \theta_{s 2}
$$

これを式 (15) に代入すると, 最大高度 $H_{0}$ は次のよう に表わされる。

$$
H_{0}=\frac{v_{s 2}^{2}}{2 g} \sin ^{2} \theta_{s 2}
$$

また, 水平到達距離 $L$ は, 式 (14) に

$$
t=2 T=2 v_{s 2} \sin \theta_{s 2} / g
$$

を代入すれば，次のようになる6)。

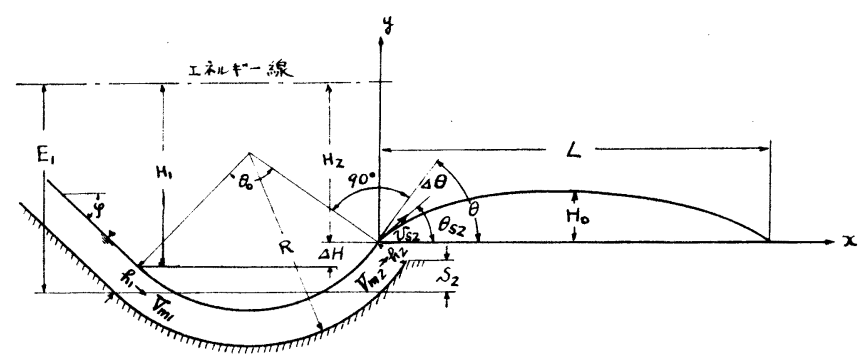

図-3 


$$
L=\frac{2 v_{s 2}^{2}}{g} \sin \theta_{s 2} \cos \theta_{s 2}
$$

これらの式から, 次式が得られる.

$$
\begin{aligned}
& v_{s 2}=\sqrt{\frac{g\left(L^{2}+16 H_{0}^{2}\right)}{8 H_{0}} \cdots} \\
& \theta_{s 2}=\sin ^{-1} \frac{4 H_{0}}{\sqrt{L^{2}+16 H_{0}^{2}}} .
\end{aligned}
$$

式 (16)，（17）より，水平到達距離 $L$ と最大高度 $H_{0}$ を 測定することにより, 円曲面から空中への射出水の初速 度 $v_{s 2}$ と, 射出角 $\theta_{s 2}$ を求めることができる.

\section{4. 実験}

\section{（1）実験設備}

実験水路は図一1, 写真一2 に示すように，水路幅 40 $\mathrm{cm}$ の斜水路の水平に対する傾斜角 $\varphi$ を， $\varphi=43^{\circ} 10^{\prime}$, $45^{\circ} 02^{\prime}, \varphi=34^{\circ} 30^{\prime}, 35^{\circ} 05^{\prime}, \varphi=23^{\circ} 52^{\prime}, 25^{\circ} 09^{\prime}, \varphi=13^{\circ} 09^{\prime}$, $14^{\circ} 54^{\prime}$ のように, 約 $10^{\circ}$ ずつ変えて, それぞれの傾斜角 $\varphi$ の斜水路に射流をおこす.この斜水路に，写真一1に 示すような凹形円曲面を, 斜水路の水路底に円曲面が接 するようにすえつけた. なお, 凹形円曲面の曲率半径と 中心角は,表一1 に示寸ものとした.円曲面終点における 接線の, 水平に対する傾斜角 $\theta$ 法，図一1 に示寸ように $\theta=\theta_{0}-\varphi$ であるが，上記のとおり斜水路の傾斜角 $\varphi$ を 変えることにより，異なる $\theta$ の円曲面について実験する こととした。 また，一つの流量に対して，円曲面のすえ つけ位置を, 斜水路の上段と下段に, 位置を変えてすえ つけて，図一1 に示す $V_{m 1}$ を変えたものについて実験 することとした.

\section{（2）実 験 要 領}

図一3 に示すように, 円曲面始点の水深 $h_{1}$ と, 終点 水深 $h_{2}$ 在測定する. すなわち, 円曲面始点または終点

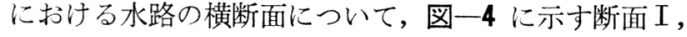
II，III 位置の水深を測定し，その平均水深をもって，始 点水深 $h_{1}$ と終点水深 $h_{2}$ とした.

本実験のような射流の水深測定にポイントゲージを使 用するとき, 針の先端が水表面に接しても判定が難しい ため, 本実験にお

いては, 針のかわ りにエッジを用い るものとし，図一 5 に示すような射 流水深測定器を試 作し，これを使用 した.

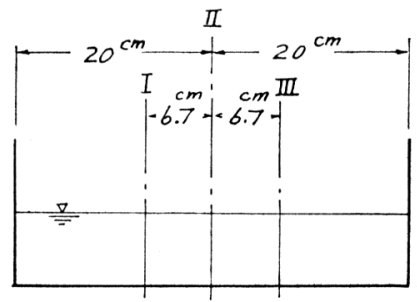

円曲面を通過後

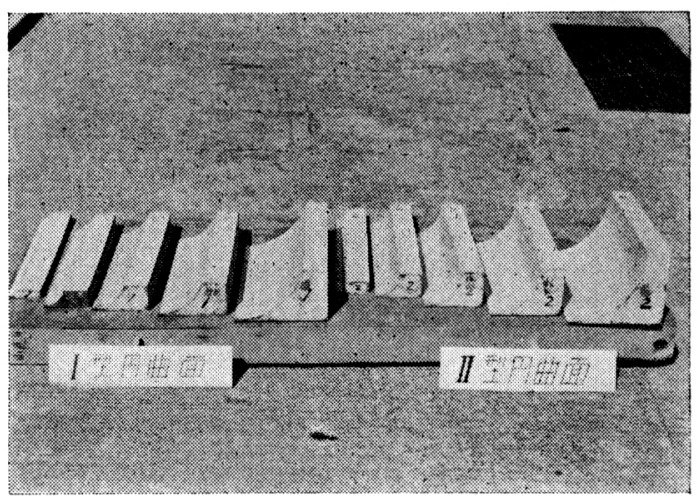

写真一1 円曲面 模 型

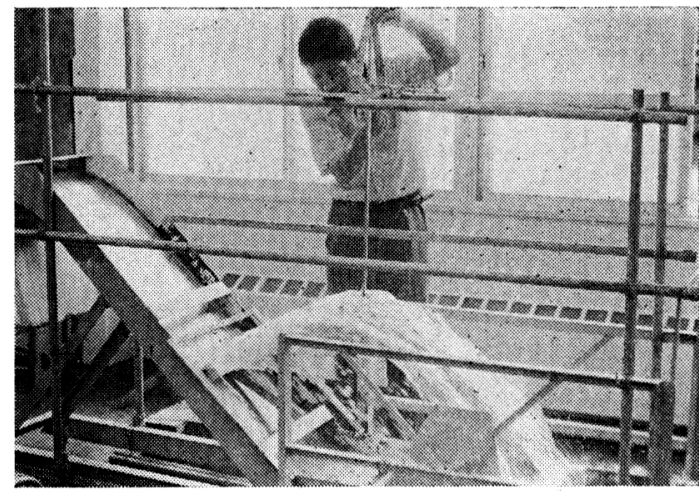

写真-2

\begin{tabular}{r|c|c}
\multicolumn{3}{c}{ 表一1 凹形円曲面模型 } \\
\hline \multirow{3}{*}{ 半 径 $R$} & 中 心 & 角 $\theta_{0}$ \\
\cline { 2 - 3 } & 1 型円曲面 & 2 型円曲面 \\
\hline $25 \mathrm{~mm}$ & $69^{\circ} 45^{\prime}$ & $91^{\circ} 15^{\prime}$ \\
$50 \mathrm{~mm}$ & $72^{\circ} 30^{\prime}$ & $91^{\circ} 30^{\prime}$ \\
$75 \mathrm{~mm}$ & $74^{\circ} 00^{\prime}$ & $92^{\circ} 00^{\prime}$ \\
$100 \mathrm{~mm}$ & $73^{\circ} 30^{\prime}$ & $92^{\circ} 30^{\prime}$ \\
$150 \mathrm{~mm}$ & $74^{\circ} 30^{\prime}$ & $93^{\circ} 30^{\prime}$ \\
\hline
\end{tabular}

の射出水は, 空気の抵抗を無視すると, すでに記述した ように放物線の径路をとるものと考える.このとき，水 平到達距離 $L$ と最大高度 $H_{0}$ についても，図一4 に示す 断面 I , II , IIIの位置について測定し，これらの平均值を 用いることとした。これらの測定も，図一6に示すよう に，ポイントゲージにエッジを取り付けたものを使用し た.

エッジの先端を円曲面終点に一致させ，ポイントゲー ジを下流側へ水平に移動して，射出水表面に，エッジの 先端が接するような位置を求めて，水平到達距離 $L$ を 測定した. また，この射出水の径路が放物線と考えられ る場合は，円曲面終点から下流側へ， $L / 2$ の位置におい て最大高度 $H_{0}$ を生ずると考えられるので，その位置で エッジの先端が水表面に接するときの読みをとり，最大 高度 $H_{0}$ を測定した. 

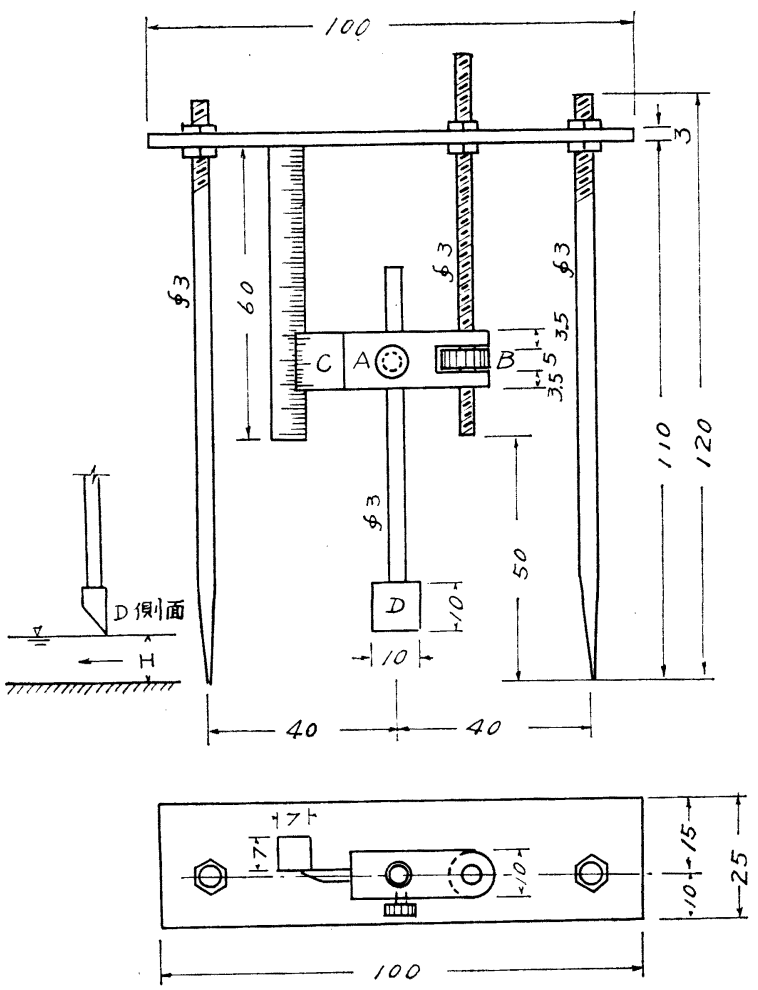

C : バーニヤ

D : エッジ

单位 $\mathrm{mm}$

図一5

これら $L, H_{0}, h_{1}, h_{2}$ の測定は, 水表面が若干 動摇して上下することが 多いので, エッジの先端 が水表面を離れている時 間と，水表面以下にある 時間とが,ほぼ同じにな るときの読みをとるもの とした ${ }^{7)}$.

表一1, 写真一1 に示 す，それぞれ 5 個の 1 型

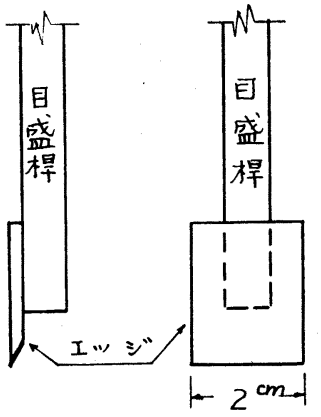

図-6
および 2 型円曲面を，斜水路の上段および下段に逐次す えつけ, 流量 $q$ または斜水路の傾斜角 $\varphi$ を変えて $q, h_{1}$, $h_{2}, L, H_{0}$ を測定した.

\section{（3）実験結果の整理}

図一3において, 円曲面始点通過直後, および終点通 過直前の水深と平均流速をそれぞれ $h_{1}, h_{2}$ と $V_{m 1}, V_{m 2}$ とし, これらの点の表面流速を $v_{s 1}, v_{s 2}$ とする.

実験結果より, 円曲面終点の射出角 $\theta_{s 2}$ と平均流速補 正係数 $K_{2}$ は, 次に表示する順序により求めることがで きる.

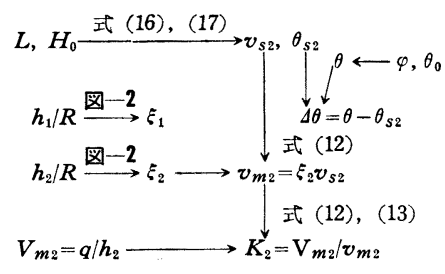

円曲面始点の平均流速補正係数 $K_{1}$ は, 次の逐 次計算により，その近似值を求めることができ る.

本実験において，表一1 の 1 型および 2 型円曲 面を斜水路にすえつける場合に，図一1に示す円 曲面の始点位置 A を一定とした．AC を水平と し，C点の水深と補正係数を, 近似的に曲面終点 $\mathrm{B}$ に打ける水深 $h_{2}$, 補正係数 $\xi_{2}$ と等しいと仮定 し, $\mathrm{OC}$ 断面の平均流速 $V_{m 2}$, 始点の平均流速 $V_{m 1}$, 終点の平均流速 $V_{m 2}$ は式 (13) より

$$
\begin{aligned}
& V_{m 1}=K_{1} \xi_{1} \sqrt{2 g H_{1}} \\
& V_{m 2}{ }^{\prime} \fallingdotseq K_{2} \xi_{2} \sqrt{2 g H_{1}} \\
& V_{m 2}=K_{2} \xi_{2} \sqrt{2 g H_{2}} \\
& =K_{2} \xi_{2} \sqrt{2 g\left(H_{1}-\Delta H\right)} \\
& =K_{2} \xi_{2} \sqrt{2 g H_{1}}\left(1-\frac{\Delta H}{H_{1}}\right)^{1 / 2}
\end{aligned}
$$

ただし， $\Delta H=H_{1}-H_{2}$ とする.

$\Delta H / H_{1}<1$ とし，上式を二項定理により展開 し，2 乗項以下を無視すれば

$$
V_{m 2} \fallingdotseq K_{2} \xi_{2} \sqrt{2 g H_{1}}\left(1-\frac{\Delta H}{2 H_{1}}\right)
$$

いま，近似的に次式が成立するものとする。

$$
\Delta H \doteqdot S_{2}
$$

また，

$$
S_{2}=2 R \sin \frac{\theta_{0}}{2} \sin \left(\frac{\theta_{0}}{2}-\varphi\right) .
$$

式 (19)，(20)，(21)より

$$
V_{m 2}{ }^{\prime}=\frac{V_{m 2}}{1-\frac{S_{2}}{2 H_{1}}}
$$

式 (18) より

$$
H_{1}=\frac{1}{2 g}\left(\frac{V_{m_{1}}}{K_{1} \xi_{1}}\right)^{2}
$$

式 (18)，(19)より

$$
\begin{aligned}
& K_{1} \fallingdotseq \frac{V_{m_{1}}}{V_{m 2}{ }^{\prime}} \frac{\xi_{2}}{\xi_{1}} K_{2} \ldots . \\
& V_{m 1}=q / h_{1}, V_{m 2}=q / h_{2}
\end{aligned}
$$

であるから， $K_{1}$ の逐次計算を次のようにした。

$K_{1}$ が末知であるから，まず， $K_{1} \doteqdot K_{2}$ とおき，すで に求まった $K_{2}$ を用いて, 式 (24) より $H_{1}$ を求める. 式 (22)，(23) によって $V_{m 2}{ }^{\prime}$ が求められ, 式 (25) に より $K_{1}$ の第 1 近似值が求められる.この $K_{1}$ の第 1 近

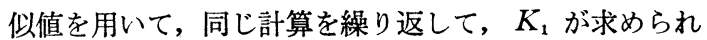


る.

\section{5. 実験結果と考察}

\section{（1）射出偏角 $\Delta \theta$}

図一3 に示すように, 円弧終点の接線の傾斜角 $\theta$ と, 円弧からの射出水の射出角 $\theta_{s 2}$ との偏角 $\Delta \theta$ は, 理論上 は $\Delta \theta=0$ であるが，水深比の大きい本実験においては， $\Delta \theta \neq 0$ であった.

斜水路の流量は直角三角ぜきにより測定し，単位幅当 りの流量 $q$ を次のようにとった.

$q=263.1 \sim 264.5 \mathrm{~cm}^{3} / \mathrm{s} / \mathrm{cm}, h_{c} \fallingdotseq 4.1 \mathrm{~cm}$ $q=362.2 \sim 370.6 \mathrm{~cm}^{3} / \mathrm{s} / \mathrm{cm}, h_{c} \doteqdot 5.2 \mathrm{~cm}$

$$
\frac{4 \theta}{\theta}=0.18 \times 3.90^{\frac{h_{0}}{R}}
$$

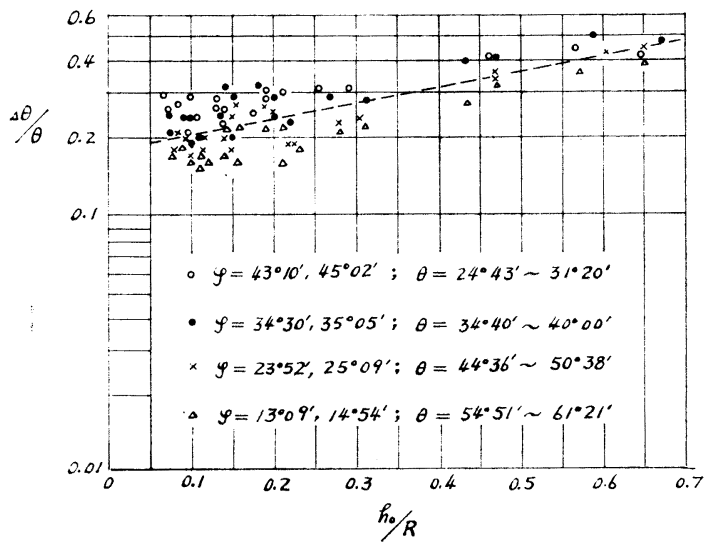

図一71型円曲面

$$
\frac{\Delta \theta}{\theta}=0.10 \times 8.62^{\frac{h_{0}}{R}}
$$

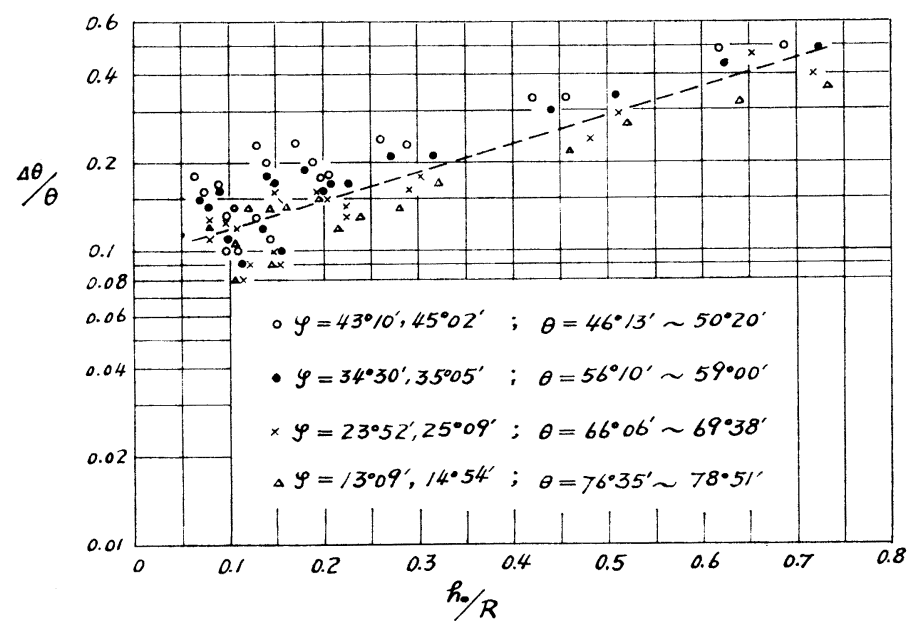

図一82 型 円曲面
表一2

\begin{tabular}{c|c|c|c}
\hline \multirow{2}{*}{ Case } & \multirow{2}{*}{ 斜水路傾斜角 } & \multicolumn{2}{|c}{ 円曲面終点の傾斜角 $\theta$} \\
\cline { 3 - 4 } & $\varphi$ & 1 型 円曲 面 & 2 型 月 曲面 \\
\hline 1 & $43^{\circ} 10^{\prime}, 45^{\circ} 02^{\prime}$ & $24^{\circ} 43^{\prime} \sim 31^{\circ} 20^{\prime}$ & $46^{\circ} 13^{\prime} \sim 50^{\circ} 20^{\prime}$ \\
2 & $34^{\circ} 30^{\prime}, 35^{\circ} 05^{\prime}$ & $34^{\circ} 40^{\prime} \sim 40^{\circ} 00^{\prime}$ & $56^{\circ} 10^{\prime} \sim 59^{\circ} 00^{\prime}$ \\
3 & $23^{\circ} 52^{\prime}, 25^{\circ} 09^{\prime}$ & $44^{\circ} 36^{\prime} \sim 50^{\circ} 38^{\prime}$ & $66^{\circ} 06^{\prime} \sim 69^{\circ} 38^{\prime}$ \\
4 & $13^{\circ} 09^{\prime}, 14^{\circ} 54^{\prime}$ & $54^{\circ} 51^{\prime} \sim 61^{\circ} 21^{\prime}$ & $76^{\circ} 35^{\prime} \sim 78^{\circ} 51^{\prime}$ \\
\hline
\end{tabular}

ここに, $h_{c}$ は限界水媣とする.

円曲面始点，終点の水深をそれぞれ $h_{1}, h_{2}$ とし，円曲 面の平均水深 $h_{0}$ を, $h_{0} \doteqdot\left(h_{1}+h_{2}\right) / 2$ とし, 平均水深比 を $h_{0} / R$ とする.

図一7 は 1 型円曲面について, 図一8 は 2 型円曲面に ついて, 平均水深比 $h_{0} / R$ と, 偏角比 $\Delta \theta / \theta$ の関係を示 す. すなわち, 片対数方眼紙の横軸に $h_{0} / R$ をとり, 縦 軸に $\Delta \theta / \theta$ をとりプロットした.

両図は相当ばらつきはあるが，最小自乗法により， $h_{0} / R$ と $\Delta \theta / \theta$ の関係を求めると次式で表わされ, これ を, 図の破線で表わした.

$$
\begin{aligned}
& 1 \text { 型円曲面 } \frac{\Delta \theta}{\theta}=0.18 \times 3.90 \frac{h_{0}}{R} \\
& 2 \text { 型円曲面 } \frac{\Delta \theta}{\theta}=0.10 \times 8.62 \frac{h_{0}}{R}
\end{aligned}
$$

また，平均水深比 $h_{0} / R$ と，偏角 $\Delta \theta$ の関係を片対数方 眼紙にプロットすると，1 型円曲面は 図一9，2 型円曲 面は 図一10 に示すとおりである.

表一2 における Case 3 の 1 型円曲面の場合上, Case 1 の 2 型円曲面の場合について, 図一7 と 図一8より, 任意の $h_{0} / R$ に対して, $\Delta \theta / \theta$ が近似した值を示すことが わかる. 寸なわち， $h_{0} / R$ と $\Delta \theta / \theta$ の相関関倸が近似して いるといえる.

また, Case 4 の 1 型円曲面の場合と, Case 2 の 2 型 円曲面の場合についても，同じことが いえる.

表一2よりわかるように, Case 3 の 1 型円曲面の場合と, Case 1 の 2 型 円曲面の場合は, 曲面終点の傾斜角 $\theta$ がほぼ等しい. また，Case 4 の 1 型 円曲面と, Case 2 の 2 型円曲面の $\theta$ も，またほぼ等しい。

また，表一1 より 1 型円曲面の中心 角 $\theta_{0}$ が, 2 型円曲面のそれより約 $190^{\circ}$ 小さい.

\section{（2）補正係数 $K_{1}, K_{2}$}

式（13）における円曲面終点の平均 流速補正俰数 $K_{2}$ と, 平均水深比 $h_{0} / R$ の関係を，両対数方眼紙にプロットす れば, 図一11 ( 1 型円曲面) と図一12 
（2 型円曲面）のとおりである.

最小自乗法により, $K_{2}$ と $h_{0} / R$ の関係を求めると, 次 式で表わされる。

1 型冈曲面

$$
K_{2}=1.25\left(\frac{h_{0}}{R}\right)^{0.10}
$$

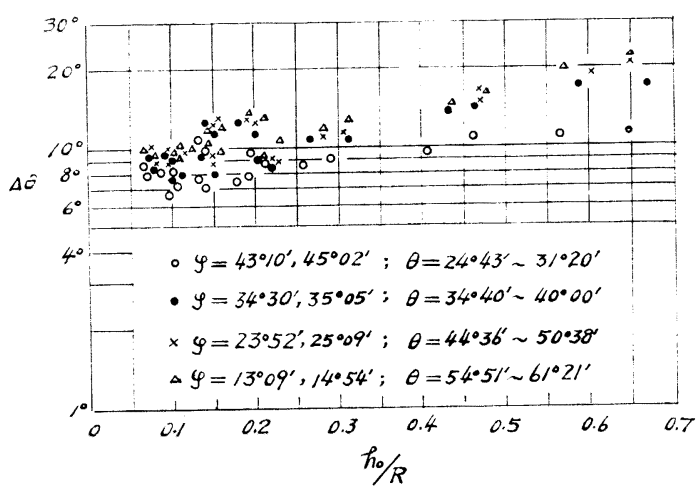

図一9 1 型 円曲面

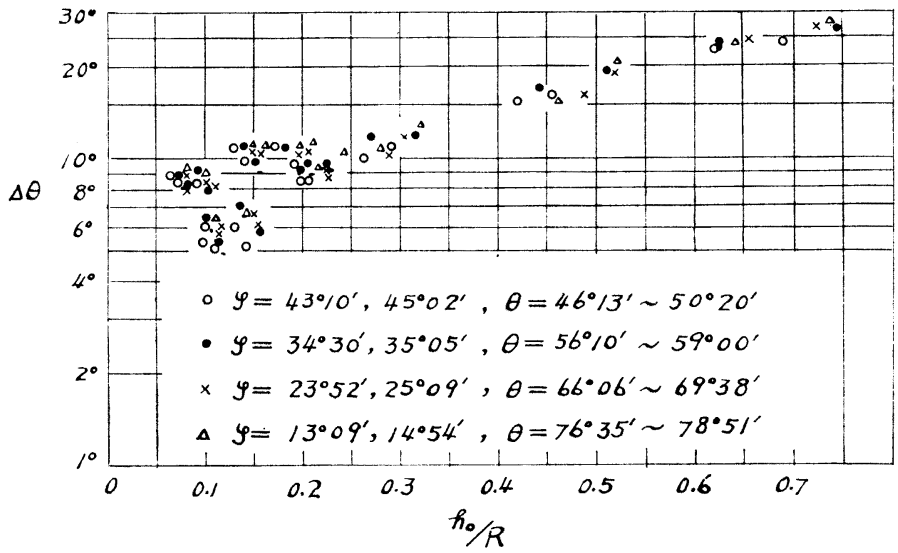

図-10 2 型円曲面

$$
K_{2}=1.25\left(\frac{h_{0}}{R}\right)^{0.10}
$$

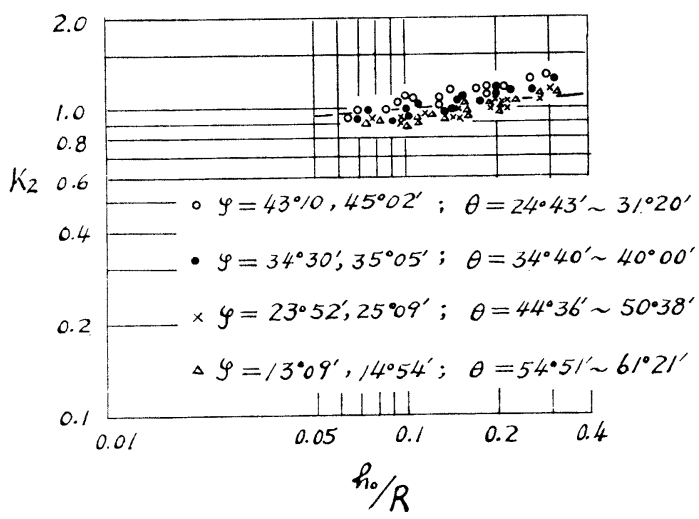

図-11 1 型円曲面
2 型円曲面

$$
K_{2}=1.25\left(\frac{h_{0}}{R}\right)^{0.12}
$$

図-11，図一12 の破線はこれらの式を表わすものと する.

上式より， 1 型円曲面については， $h_{0} / R \leqq 0.1$ のと き $K_{2} \leqq 1$ となり, $h_{0} / R>0.1$ のとき $K_{2}>1$ となる

また， 2 型円曲面については， $h_{0} / R \leqq 0.15$ のとき $K_{2} \leqq 1$ となり, $h_{0} / R>0.15$ のとき $K_{2}>1$ となるこ とがわかる.

1 型および 2 型円曲面に おいて 水深比が 小さい場合 は，その平均流速が摩擦の影響が大きく $K_{2}<1$ となる ものと考える.

円曲面始点の平均流速補正係数 $K_{1}$ と, 水深比 $h_{0} / R$ の関係を, 片対数方眼紙にプロットすれば, 図一13 ( 1 型円曲面) と 図一14 ( 2 型円曲面) に示すとおりであ る.

最小自乗法により， $K_{1}$ と $h_{0} / R$ の関係を求めると次式 を得た。

1 型円曲面

$$
K_{1}=0.077\left(\frac{h_{0}}{R}\right)+1.03 \cdots(30)
$$

2 型円曲面

$$
K_{1}=0.016\left(\frac{h_{0}}{R}\right)+1.03
$$

図一13，図一14において，破線はこれ らの式を表わす.

これらの式からわかるように, $h_{0} / R$ が 大きくなっても， $K_{1}$ の值はあまり変わ らない. 4.(3) 実験結果の整理の項にお いて記述したように， $K_{1}$ の值は近似計 算であるので, $K_{1}$ は $h_{0} / R$ に関係なく， $K_{1} \fallingdotseq 1$ と考えるのが妥当でないかと考え

$$
K_{2}=1.25\left(\frac{h_{0}}{R}\right)^{0.12}
$$

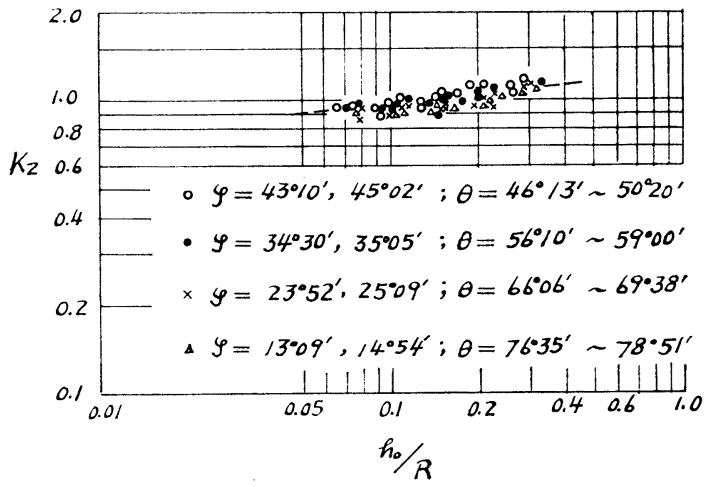

図-12 2 型円曲面 


$$
K_{1}=0.077\left(\frac{h_{0}}{R}\right)+1.03
$$

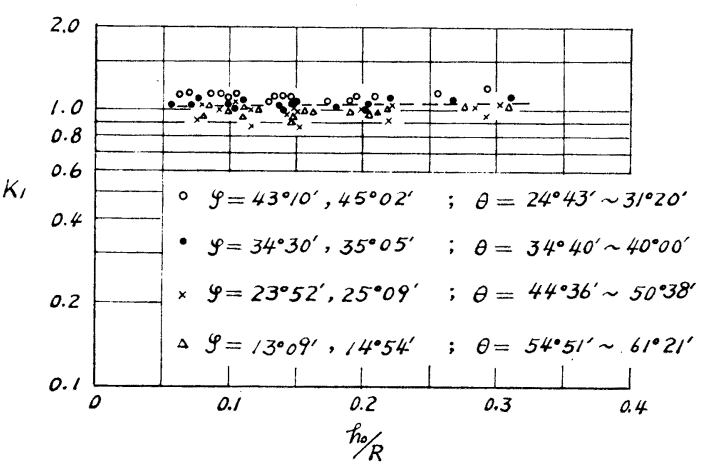

図-13 1 型 円曲面

$$
K_{1}=0.016\left(\frac{h_{0}}{R}\right)+1.03
$$

K,

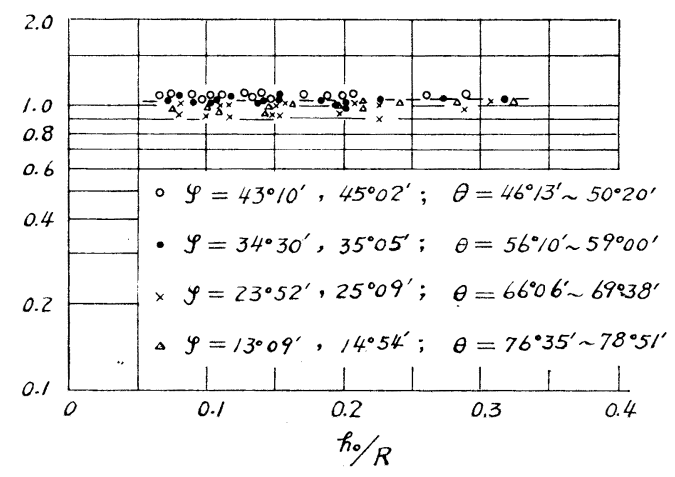

図-14 2 型 円曲面

る.

図一1 に示すように, 円曲面始点と終点の高さの差を $S_{2}$ とし, 始点の比エネルギーを $E_{1}$ とするとき, 本実験 における $S_{2} / E_{1}$ の值は次のとおりである.
$S_{2} / E_{1}<0.05$ の実験個数 56 個
$0.05<S_{2} / E_{1}<0.10$ の実験個数 34 個
$0.10<S_{2} / E_{1}$ の実験個数 34 個
全実験個数 124 個

\section{6. 実験成果の検討}

本実験においては上記のとおり，図一3に示すように， 円曲面から空中一の射出水脈の最大高度 $H_{0}$ と, 水平到 達距離 $L$ を測定し, これらから円曲面終点の表面流速 $v_{s}$ を求め, 式 (13), すなわち

$$
V_{m}=K \xi \sqrt{2 g\left\{E_{1} \pm S-h \cos (\theta-\varphi)\right\}}
$$

における平均流速補正係数 $K$ を求めた. その実験成果 は, 図一11，図一12 に示した.この実験成果のチェッ クとして, 次のような実験を行った。

図一1について, 斜水路の水平に対する傾斜角を $\varphi$,
斜水路上に設けた円曲面の始点から斜水路へ流入直前の 水平水路床までの高さを $z_{0}$, 単位幅当りの流量を $q$, 円 曲面始点の水路床からエネルギー線までの高さを $E_{1}$ と する.

半径 $R=30 \mathrm{~cm}$, 中心角 $\theta_{0}=85^{\circ}, 100^{\circ}, 115^{\circ}$ の円曲面 を，それぞれ斜水路上にすえつけ，次の場合について実 験した。

(i) $\varphi=42^{\circ} 38^{\prime}, q=752.5 \mathrm{~cm}^{3} / \mathrm{s} / \mathrm{cm}$ $z_{0}=38.45 \mathrm{~cm} \sim 38.67 \mathrm{~cm}$, $E_{1}=51.24 \mathrm{~cm} \sim 51.32 \mathrm{~cm}$

(ii) $\varphi=42^{\circ} 38^{\prime}, q=1041.4 \mathrm{~cm}^{3} / \mathrm{s} / \mathrm{cm}$ $z_{0}=38.45 \mathrm{~cm} \sim 38.67 \mathrm{~cm}$, $E_{1}=54.13 \mathrm{~cm} \sim 54.36 \mathrm{~cm}$

(iii) $\varphi=50^{\circ} 22^{\prime}, q=752.5 \mathrm{~cm}^{3} / \mathrm{s} / \mathrm{cm}$ $z_{0}=44.56 \mathrm{~cm} \sim 44.83 \mathrm{~cm}$, $E_{1}=57.27 \mathrm{~cm} \sim 57.50 \mathrm{~cm}$

(iv) $\varphi=50^{\circ} 22^{\prime}, q=1029.4 \mathrm{~cm}^{3} / \mathrm{s} / \mathrm{cm}$ $z_{0}=44.56 \mathrm{~cm} \sim 44.83 \mathrm{~cm}$, $E_{1}=60.18 \mathrm{~cm} \sim 60.45 \mathrm{~cm}$

図一1において，任意の中心角 $\theta$ における断面亚の平 均流速補正係数 $K$ は, 次のようにして求めることがで きる.

斜水路一流入直前断面の水平水路について，水路床か らエネルギー線までの高さ $E_{0}$ を求める. この断面から 下流の損失水頭を無視すると, 円曲面始点の水路床から エネルギー線までの高さ $E_{1}$ は， $E_{1}=E_{0}+z_{0}$ により求 められる. また, 円曲面始点と断面亚の水路床の高さの 差 $S$ を測定する. 断面亚の水深 $h$ を測定し, 図一2 を 用いて $h / R$ から遠心力係数 $\xi$ が求められる. 断面の 平均流速 $V_{m}$ は, $V_{m}=q / h$ であるから, 以上の諸值を 式 (13) に代入して, 断面亚の平均流速補正倸数を求め ることができる.

本研究の図一11, 図一12 と対照するために, $\theta=75^{\circ}$, $\theta=90^{\circ}$ の断面について $K$ の值を求め, 両対数方眼紙に プロットすれば, 図一15, 図一16 に示すとおりである. 本研究による 図一11, 図一12 と, この実験による図一 15，図一16 の成果は，ほぼ近似しているものといえる. 次住, 円曲面の始点, すなわち, $\theta=0^{\circ}$ の断面につい て, 同じ方法により, $K=K_{1}$ の值を求めると, 次のと おりである.

$$
\begin{aligned}
\varphi=42^{\circ} 38^{\prime}, h / R & =0.083 \sim 0.085 \text { のとき } \\
K_{1} & =0.99 \sim 1.01 \\
\varphi=42^{\circ} 38^{\prime}, h / R & =0.113 \sim 0.114 \text { のとき } \\
K_{1} & =1.00 \sim 1.03 \\
\varphi=50^{\circ} 22^{\prime}, h / R & =0.080 \sim 0.082 \text { のとき } \\
K_{1} & =0.96 \sim 0.98 \\
\varphi=50^{\circ} 22^{\prime}, h / R & =0.108 \sim 0.112 \text { のとき }
\end{aligned}
$$




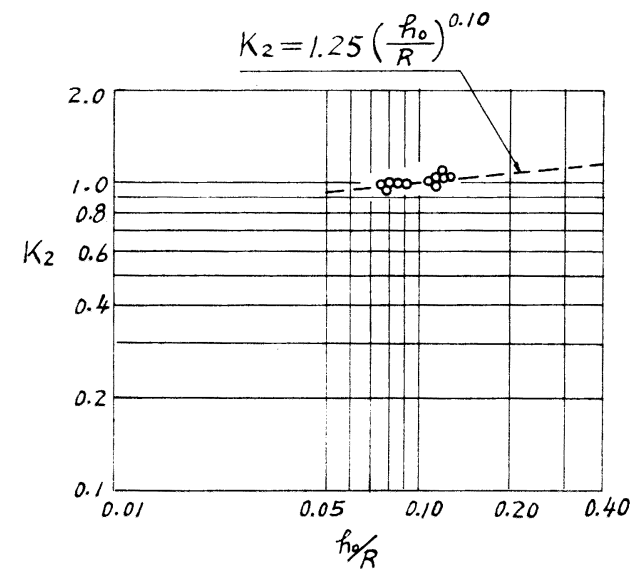

図-15 $R=30 \mathrm{~cm} \quad \theta=75^{\circ}$

$$
K_{1}=0.97 \sim 1.00
$$

$K_{1}$ の值は, 本研究においては, 図一13, 図一14のと おりであるが， $K_{1} \doteqdot 1$ とするのが妥当であると記述し た.

この実験による $K_{1}$ の值も上記のとおり， $K_{1}=0.96$ 1.03 の範囲にばらついており， $K_{1} \doteqdot 1$ とするのが適当 でないかと考える.

\section{7. むすび}

凹形円曲面上の平均水哚比 $h_{0} / R$ の大きい流れについ て実験をし，その結論を要約すると，次のとおりであ る.

（1）平均水深比 $h_{0} / R$ が大きい円曲面上の流れの， 円曲面の始点と 終点の平均流速を $V_{m 1}, V_{m 2}$ とすると き, 次式が成立するものとする.

$$
\begin{aligned}
& V_{m 1}=K_{1} \xi_{1} \sqrt{2 g H_{1}} \\
& V_{m 2}=K_{2} \xi_{2} \sqrt{2 g H_{2}}
\end{aligned}
$$

ここに,

$K_{1}, K_{2}$ : 円曲面始点, 終点の平均流速補正係数 $\xi_{1}, \xi_{2}$ : 円曲面始点, 終点の遠心力係数

$H_{1}, H_{2}$ : 円曲面始点, 終点の水面からエネルギー 線までの高さ

円曲面始点の平均流速補正係数 $K_{1}$ は，1 型および 2 型円曲面とも， $h_{0} / R$ にあまり関係せず, 近似的に $K_{1} \doteqdot 1$ と考えるのが妥当でないかと考える.

また, 円曲面終点の平均流速補正係数 $K_{2}$ は, 最小自 乗法により次式を得た。

1 型円曲面

$$
K_{2}=1.25\left(\frac{h_{0}}{R}\right)^{0.10}
$$

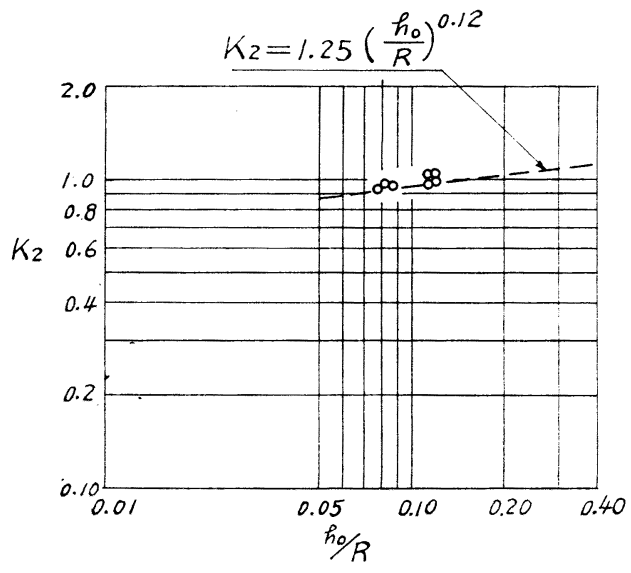

図-16 $R=30 \mathrm{~cm} \quad \theta=90^{\circ}$

2 型円曲面

$$
K_{2}=1.25\left(\frac{h_{0}}{R}\right)^{0.12}
$$

すなわち， 1 型円曲面においては， $h_{0} / R=0.1$ のとき $K_{2} \fallingdotseq 1.00$ であるが, $h_{0} / R$ が大きくなるに従って $K_{2}$ も 大きくなり $h_{0} / R=0.3$ のとき $K_{2} \fallingdotseq 1.11$ となるものと 考える.

また， 2 型円曲面については， $h_{0} / R=0.15$ のとき $K_{2}$ $\doteqdot 1.00$ となるが, $h_{0} / R=0.3$ のとき $K_{2} \fallingdotseq 1.08$ となる ものと考える.

（2） 円曲面終点に打ける円曲面接線の傾斜角 $\theta$, そ の終点から空中への射出水の射出角 $\theta_{s 2}$, 射出偏角 $\Delta \theta$ を $\Delta \theta=\theta-\theta_{s 2}$ とする.

a) $\Delta \theta / \theta$ は $h_{0} / R$ が大きくなるに従って大きくなる.

b) $\Delta \theta / \theta$ の $h_{0} / R$ 関係は, 最小自乗法により次式を得 た.

1 型円曲面 $\left(\theta \fallingdotseq 25^{\circ} \sim 61^{\circ}\right)$

$$
\frac{\Delta \theta}{\theta}=0.18 \times 3.90 \frac{h_{0}}{R}
$$

2 型円曲面 $\left(\theta \fallingdotseq 46^{\circ} \sim 79^{\circ}\right)$

$$
\frac{\Delta \theta}{\theta}=0.10 \times 8.62 \frac{h_{0}}{R}
$$

すなわち， 1 型円曲面においては，

$h_{0} / R=0.10$ のとき $\Delta \theta / \theta \fallingdotseq 0.21$

$h_{0} / R=0.30$ のとき $\Delta \theta / \theta \doteqdot 0.27$

$h_{0} / R=0.60$ のとき $\Delta \theta / \theta \doteqdot 0.41$

また， 2 型円曲面においては，

$h_{0} / R=0.10$ のとき $\Delta \theta / \theta \fallingdotseq 0.12$

$h_{0} / R=0.30$ のとき $\Delta \theta / \theta \fallingdotseq 0.19$

$h_{0} / R=0.60$ のとき $\Delta \theta / \theta \fallingdotseq 0.36$

となることが考えられる.

以上のように, 水深比の大きい円曲面上の流れにおい 
ては, 平均流速や射出偏角比 $\Delta \theta / \theta$ にとって, 水樑比 $h_{0} / R$ が重要な因子となるものと考える.

最後に, 大阪市立大学工学部 永井荘七郎教授に適切 なご助言をいただいた．紙面をかりて謝意を表する次第 である。

$$
\text { 考支 献 }
$$

1）土木学会 : 海岸保全施設設計便覧改訂版, pp. 213～214.
2) 細井正延・杉山錦雄 : 水理学, p. 203.

3) Chow V.T.: Open Channel Hydraulics, McGrawHill, p. $30 \sim 32,1959$.

4) 石原藤次郎・本間 仁: 応用水理学, 中 I, p. 126 .

5）川上謙太郎：ノッズル・ゼットの水平到達距離に関する 研究, 土木学会論文集, No. 191, 1971-7, p. 88.

6) 永井荘七郎 : 改訂水理学, p. 152.

7）石原藤次郎・本間 仁：応用水理学, 下 I. p. 105. 